Information Management and Business Review

Vol. 7, No. 1, pp. 48-58, February 2015 (ISSN 2220-3796)

\title{
The Dynamics of Value Creation in Online Brand Communities: Strategy Map Approach
}

\author{
Rizwan Shabbir*1, Jing Zhang1, Chatchai Pitsaphol ${ }^{1}$, Waseem Hassan ${ }^{2}$ \\ ${ }^{1}$ Huazhong University of Science and Technology, Wuhan, P.R. China \\ ${ }^{2}$ China University of Geosciences, Wuhan, P. R. China \\ *rizwanshabbir@hust.edu.cn
}

\begin{abstract}
As the clout of social networking is growing, brand managers are exploring diversified marketing strategies and consumer attitudes. The current study reveals the impact of value creation practices and brand loyalty in online brand communities based on perceived benefits enjoyed by consumers. Based on quantitative research approach, a sample of 308 respondents were collected to investigate relationships among online brand community participation, value creation practices and brand loyalty. The results highlighted hedonic, learning, self-esteem and social benefits as antecedents for online brand community participation. Moreover, value creation practices are derived as essential factor for enhancing brand loyalty among online community members. The finding exhibited valuable insights about developing corporate strategies to achieve customer intimacy for long-term relationship. Managerial implications are explained by identifying value-creation practices as a mechanism for enhancing consumer engagement and relationship management.
\end{abstract}

Keywords: Brand community, Brand loyalty, Online Brand Community, Perceived benefits, value Creation

\section{Introduction}

Brand management in recent years has focused on brand communities to flourish and enhance relationship with existing and new consumers of a product/service. From consumer perspective, the brand is a promise which developed relationship satisfaction by using various combinations of attributes for making a purchase decision (Ambler, 1992). Thus, Branding is a procedure based on unique aspects and perception of customer mind about a product/service by adopting various integrated marketing communications (IMC) that create recognition by differentiating the product from rivals with an aim to attract consumers. According to Keller (1993), the quality of resonance recognizes the intensity among the brand and customer. At this stage, consumers devote themselves for the success and interact with other loyal consumers through different marking communication activities. Therefore, consumers attitude towards a particular brand generate intentions to participate and enhance experience that produce emotional attachment, relationship building and endorsement (Ouwersloot \& Odekerken-Schröder, 2008).

The brand communities (BCs) have a quite long history but mostly those brand communities used offline communications techniques to build brand loyalty. These BCs provide different venues for members to share their experience and information about the brand, fixing problems of other members and enjoying parties with peer-members and company officials (McWilliam, 2000). The internet transformed these brand communities into online brand communities (OBCs), where consumer can establish a non-geographical bound. The multinational organizations have recognized the imperative role of online brand communities in building consumer-brand relationship and consumer-consumer relationship; these bonding facilitate the development of sustainable brand loyalty (Dholakia, Bagozzi \& Pearo, 2004). In the present age, people allocate more than one-third of their walking day in surfing social media and analyzing contents on different online social networking sites (Habibi, Laroche \& Richard, 2014). Such particular aspects of social networking and its enormous usability have transformed branding practices (Hanna, Rohm \& Crittenden, 2011). The work of Powers et al. (2012) concluded that social media have revolutionized consumer psychology from searching product/brand information to making an actual purchase decision. The purchase decisions are further analyzed through opinions given on social media by other users for making a re-purchase decision. 
The adoption and popularity of social media create opportunities for brand managers to understand the behavior of OBC participants and how to act on social media to extract valuable information and value creation techniques. To address this research gap, we summarize relevant literature of brand communities and brand management. Particularly, we reviewed antecedents for brand communities' participation and their role in building value for consumer. As, online brand communities are part of intangible assets for organization. Therefore, a need to identify tools for maintaining such competitive advantage is examined by perceived benefits provided to consumers in online brand communities. In this study, we examined four diverse drivers of online brand community participation; their ties with value-creation practices (Schau et al., 2009) that built structural bonding with brand based on consumer knowledge (McAlexander et al., 2002). Secondly, the relationship between online brand community participation and brand loyalty is investigated to evaluate the strength of relationship management.

\section{Literature Review}

The social networking sites have led marketing activities to a new platform which is associated with brand affiliations, social factors and psychological factors. A lot of academic research as well as industrial projects have given attention to probe the role of online brand communities in brand management. Therefore, the communication channels and information exchange become decisive source for customer satisfaction and relationship management (Andersen, 2005). Mostly, international brands have set-up a network of online brand communities that are connected for engaging consumers in various activities which influence their societal status and brand advocacy.

Online Brand Communities (OBCs): According to Wirtz et al. (2013) the participation of consumer in brand community events are physical and bounded within a region but social networking sites expand their events globally by providing a virtual space for various activities. The work of Muniz \& O'Guinn (2001) defined the term brand community as "specialized, non-geographically bound community, and based on a structured set of social relations among admirers of a brand" (p. 412). This explanation classified offline brand communities (Schouten, McAlexander, \& Koenig, 2007) as well as online brand communities (Adjei, Noble \& Noble, 2010). Brand communities contributed a lot for a brand through different constructs like; retrieving valuable information about new product developments, activities to strengthen brand loyalty and brand awareness (McAlexander et al., 2002), encouraging highly loyal consumer to share information and experience (Andersen, 2005) and involving consumer for co-creating value (Schau et al., 2009).

Perceived Benefits of Online Brand Communities (OBCs): To design strategies for prosperous customerbrand relationship, marketers need to find specific perceived benefits that boost consumer participation, interaction and engagement in different brand activities. Many scholars have identified various attributes that motives consumers to perform activities in OBCs. Such as; Dholakia et al. (2004) proposed five motives based on uses and gratification perspective as purposive, social-enhancement, self-discovery, interpersonal interconnectivity and entertainment. These motives concluded social influential attributes that increase consumer engagement. However, the study of Wang \& Fesenmaier (2004) and Sicilia \& Palazon (2008) analyzed consumer participation through four groups of drivers that are: function-based, psychological-based, social-based and hedonic-based. Moreover, the work of Yen, Hsu, and Huang (2011) arranged these factors into three groups for investigating member experience within a brand community. These groups involve selfenhancement factors, rewarding factors and problem resolving factors Prior studies mentioned social and psychological drivers which a little consideration to virtual environment.

For this study, we organized OBC perceived benefits in four categories grounded on the work of Katz, Gurevith \& Haas (1973) and virtual interaction attributes. These categories constitutes on learning benefits, social benefits, self-esteem benefits and hedonic benefits. Leaning benefits carried information and productknowledge related features for providing product support and guidance to consumer about the brand and its products. As, consumers enter in a virtual environment by following/liking an OBC or contributing some facts about product/brand with other users. Moreover, learning benefits guide consumers to built archive and collect information while, instrumental features involves problem-solving support activities and mentoring new community members (Nambisan \& Baron, 2009; Yen et al., 2011). Second group of attributes comprised on social benefits that maximize participation of consumers in an $\mathrm{OBC}$ through their knowledge like 
friendship, social bonds, appreciations and encouragements. Third group of attributes consists on self-esteem benefits that belong to fame and status which consumer seek in a network. Particularly, in virtual environments users gain points or rank by guiding other community members, inviting new members for sharing special techniques regarding brand/product and mentoring non-members to become an active participant in promoting brand events (Dholakia et al., 2004; Sicilia \& Palazon, 2008). Fourth group of attributes include hedonic benefits which are associated with entertainment factors that consumer find after joining a community. It provides various pleasuring opportunities for community members such as: online games, users made advertisements/cartoons and old/new promotional campaigns. With respect to virtual environment, hedonic benefit is the vital reason for consumers to join and allocate leisure time for brand events (Wang \& Fesenmaier, 2004).

Based on literature, we proposed following hypotheses:

$H_{1 a}$ : Learning benefits positivity influence online brand community participation.

$H_{1 b}$ : Social benefits positivity influence online brand community participation.

$H_{1 c}$ : Self-esteem benefits positivity influence online brand community participation.

$H_{1 d}:$ Hedonic benefits positivity influence online brand community participation.

Strategy Mapping Approach: We adopted the approach of strategy mapping from the work of Kaplan \& Norton (2000) by describing objectives related to revenue and production. Organizations require mechanism for delivering brand strategies in-order to customer value. Kaplan and Norton (2000) developed a strategy map that worked as a mechanism for improving shareholder value. For this study, we focused on the customer value proposition with regards of revenue growth strategy. This mapping technique showed causeand effect relationship that produce outcome which enhance customer retention and organizational capabilities. In the age of ICTs, organizations are creating and using their intangible assets such as customer relationships, innovations ideas, communication technologies and customer knowledge to gain competitive advantage in market place. There are three basic customer value proposition strategies, organization select one of these to gain competitive advantage (Kaplan \& Norton, 2000).

1. Operational excellence provides benefits like competitive pricing, product quality, fast-order operations \& on-time delivery.

2. Customer intimacy expertise offer specialized services to consumers and generating long-lasting relationships.

3. Product leadership value propositions provide unique methods in production or services that create differentiation at marketplace.

Visualizing Value Creation in OBCs: The work of Schau et al. (2009) described four classifications of practices from which consumers could construct value in a brand community which involves practices like: social networking, community engagement, impression management and brand use. Prior studies revealed that the relationship between firms and consumers is a two-way process in which firms provide products, benefits and platforms for activities while consumers guide them in co-creation, product innovation and value creation. The practice of social networking is an attempt to pursuit the drivers that enhance and develop relationship between consumers with a community. It indicates the members' behavior and similarities that are viable for the brand extensions and enduring relationships. The study of Schau et al. (2009) comprised social networking practice as welcoming, associating and governing the community members of a brand. The purpose of welcoming is to appreciate new community members, guiding them in learning about brand values and helping them in creating connection with other community members.

Brand community engagement trait serves as a platform for consumers and organizations for establishing relationship. In value creation, the purpose of community engagement is to boost brand value and association through brand community. It comprise on staking, mile-stoning, badging and documenting persuasive events like personal experiences of community members with products (Schau et al., 2009). With respect to OBCs, value creation also incorporates consumer behavior by means of influencing the perception of users about an event/activity organized for brand which is known as impression management. According to the study of Schau et al. (2009) impression management is described as "activities that have an external, outward focus on creating favorable impressions of the brand, brand enthusiasts and brand community in the social university beyond the brand community (p. 34)". Impression management process is categorized as evangelizing and 
justifying. Prior studies also discussed impression management while analyzing online brand communities, like Muniz and Schau's (2005) described that community members use their information to get involved in events or problem solving discussions for achieving popularity within the community. Thus, OBC provide platform for various promotional campaigns such as boosting WOM activities, sharing personal brand stories and influencing consumer's perception. By implement impression management process users spread promotional news, advancements and beliefs through interaction with different people which transform as an inspiration for those consumers. The fourth group of practices in value-creation, based on the study of Schau et al. (2009) is brand use practices which emphasis on promoting and enhancing methods of brand use. In brand use practices, the purpose of grooming is to share knowledge about caring/usage of brand and active newly connected members in community activities by transforming responsibilities during special events. After then, customizing practices involves reshaping or adjusting product/brand attributes based on community needs because members want customize the product/brand. It also increase efficiency and boost other members to participate with something interesting that develop attraction for consumers to join online brand community.

$\mathrm{H}_{2}$ : Online brand community participation has a positive influence on Value creation practices.

Consumer expertise are the variables that moderator the impact of $\mathrm{OBC}$ participation which is described as a consumer perception to be knowledgeable, experienced and skilled about a brand/product (Adjei et al., 2010). In virtual environments, members of brand communities reduce risk associated with the product/brand because those members have high product information and knowledge. Brand loyalty in terms of relationship is also high for those consumers, who participate in value creation practices (Thompson \& Sinha, 2008). Thus, we propose that customer knowledge also influence the relationship between online brand community and value creation practices.

$H_{3}$ : Consumer knowledge has a positive impact on the relationship of $O B C$ participation and Value creation practices

The study of Kozinets et al. (2010) concluded that it very complex to differentiate the impression management and brand use practices because community members always attempt to get personal satisfaction while utilizing these value-creation practices. Thus, we proposed that:

$H_{4 a}$ : Online brand community participation positivity influence overall brand loyalty.

$H_{4 b}$ : Value creation practices positivity influence overall brand loyalty.

Theoretical Framework: The study of Tajfel \& Turner (1985) pointed out social identity theory which illustrated why users affiliate with brand community. Based on this theory, consumers build their social identities and divide themselves into specific societies that allow users to accomplish their needs and affiliations in terms of brand name/logo (Grayson \& Martinec, 2004). On the contrary, Coleman (1988) explained the concept of social capital which described that brand communities is a type of social network by which users achieve social capital such as sharing brand experience and information(Muniz \& O'Guinn, 2001) and achieving functional and hedonic benefits by participating in brand communities. Therefore, we concluded that consumers attain social capital after engaging and participating in various brand communities. Thus, to maintain value-creation through online brand communities the relationship among consumers and marketers played a vital role in building strong brands. In the Current era, value creation is associated as an intangible driver for brand equity because if marketing strategies are based on customer value, the outcome should provide higher revenues and loyal customers. Moreover, through value creation organizations should get competitive advantage in the industry. To achieve value creation for a brand, the initial phase is to figure out the drivers and connection of customer value within the organization and marketplace. Thus, to learn what creates customer-value will help marketing managers to recognize the brand advocacy and potential growth for loyal consumers as shown in (Figure .1). 
Figure 1: Proposed framework for value creation and brand loyalty in $\mathrm{OBC}$

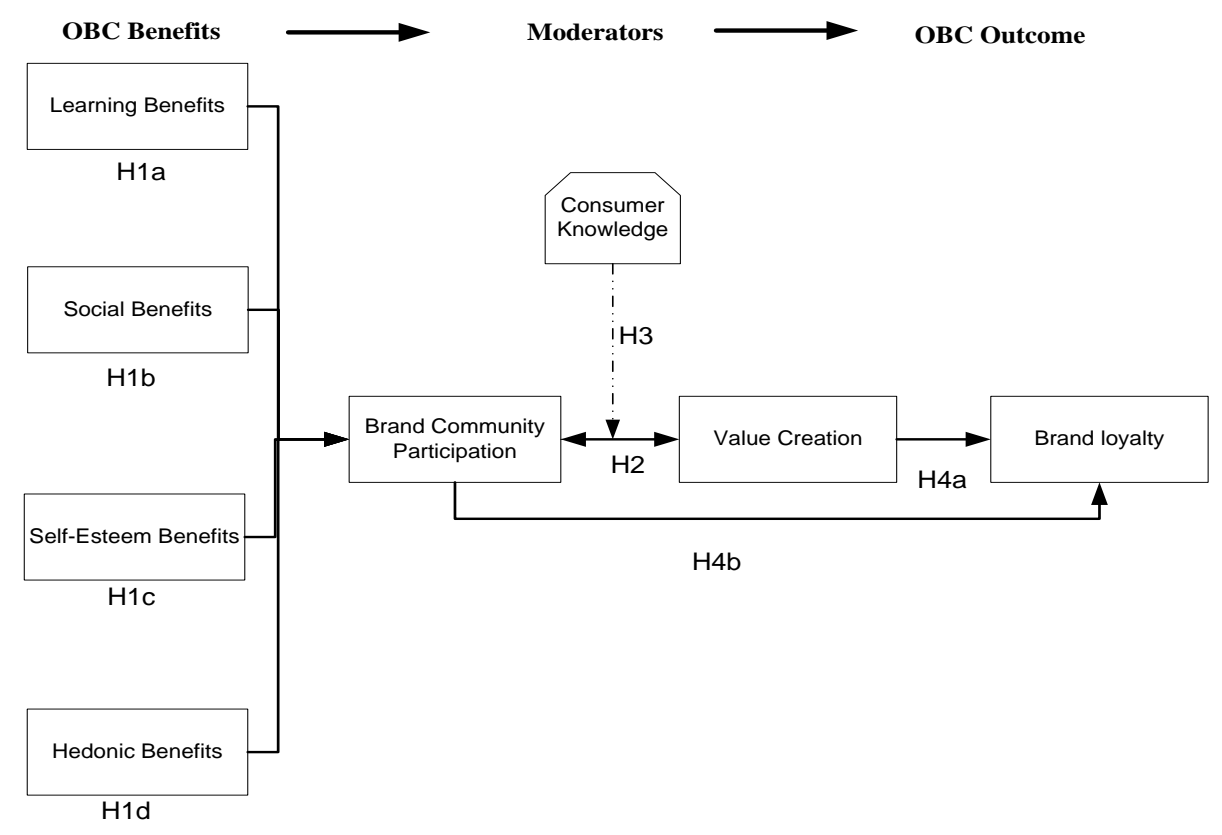

\section{Methodology}

Measures are borrowed from prior studies due to their reliability and validity regarding language and context. The scales used in these studies consist on 5-point likert scale but for comprehensive investigation these scales are expanded to 7-point likert scaling from "strong disagree to strongly agree". Therefore, items regarding learning benefits in an $\mathrm{OBC}$ are adopted from the work of Yen et al. (2011) \& Wang and Fesenmaier (2004) which comprise on three variables problem solving, increasing knowledge and technical support. Learning benefits has shown cronbach's alpha of 0.834 . Items related to social benefits are borrowed from Nambisan and Baron (2009) \& Dholakia et al. (2004) which include expanding social network, share common interest and strengthen connections. The cronbach's alpha for social benefits is reported as 0.831 . Self-esteem benefits depicted a cronbach's alpha of 0.906 which include variables about enhancing status, sense of satisfaction and increasing creditability that are borrowed from Sicilia and Palazon (2008). Items related to hedonic benefits are adopted from the study of Wang and Fesenmaier (2004) which involves variables: feel pleased, gain joy and happiness and feel inspired. It presented a cronbach's alpha of 0.891. OBC participation items are adopted from Woisetschläger, Hartleb \& Blut (2008) which showed a cronbach's alpha of 0.907 and comprised on three items. Value creation variables are adopted from the study of Schau et al., (2009) which comprise on eight variables by presenting cronbach's alpha of 0.943 . We asked respondents about their overall brand loyalty behavior, thus it consists of three items borrowed from Yoo, Suh \& Lee (2002) which depicted cronbach's alpha of 0.820 .

We preferred netnography research technique because our research objectives are based on internet sampling and it explores individual's behaviors through online research technique which present value insights (Kozinets, 2009). A fully structured questionnaire was posted on internet that links with different social networking sites. A pilot study was conducted to analyze the reliability and language of the constructs, later that webpage was opened for response. In sum, 587 users viewed that webpage but 308 out of 524 submitted complete responses that account for $58.77 \%$ response rate. The statistical investigation was conducted through principal component analysis, bivariate and multivariate analyses. (Table 1) provide the 
snapshot of demographic profile of 308 respondents. The results showed that $63.3 \%$ of respondents are females and $36.7 \%$ are males and majority of them belong to $21-30$ years that showed $48.7 \%$ representation followed by $31-40$ years which represented $30.5 \%$ of total sample. The education attained by respondents showed that $45.1 \%$ of respondents have completed their graduation. Moreover, majority of respondents are enrolled as students that depicted $39.9 \%$ followed by office employee with represent $20.1 \%$ of total sample. Usage of internet is key variable for exploring individual's behavior on OBC. The results presented that $42.5 \%$ of respondents use internet about 4 to 6 hours while $33.1 \%$ of respondents use internet more than 7 hours.

Table 1: Demographic profile of respondents

\begin{tabular}{|c|c|c|c|}
\hline Variable $(\mathrm{N}=308)$ & & Frequency & Percentage (\%) \\
\hline \multirow{4}{*}{ Age in years } & Less than 20 & 23 & 7.5 \\
\hline & $21-30$ & 150 & 48.7 \\
\hline & $31-40$ & 94 & 30.5 \\
\hline & 41 or above & 41 & 13.3 \\
\hline \multirow{5}{*}{$\begin{array}{l}\text { Education } \\
\text { attained }\end{array}$} & High school or below & 17 & 5.5 \\
\hline & Junior College & 13 & 4.2 \\
\hline & Undergraduate & 139 & 45.1 \\
\hline & Postgraduate or above & 136 & 44.2 \\
\hline & Others & 3 & 1.0 \\
\hline \multirow{3}{*}{ Gender } & Male & 113 & 36.7 \\
\hline & Female & 195 & 63.3 \\
\hline & $3,000 \mathrm{RMB}$ or Less & 141 & 45.8 \\
\hline \multirow{4}{*}{$\begin{array}{l}\text { Family income } \\
\text { per month }\end{array}$} & $3,001-5,000 \mathrm{RMB}$ & 74 & 24.0 \\
\hline & 5,001- 8,000 RMB & 44 & 14.3 \\
\hline & 8,001 - 12,000 RMB & 16 & 5.2 \\
\hline & 12,001RMB or More & 33 & 10.7 \\
\hline \multirow{8}{*}{ Occupation } & Office worker & 62 & 20.1 \\
\hline & Govt. employee & 59 & 19.2 \\
\hline & Professional & 15 & 4.9 \\
\hline & Business owner & 36 & 11.7 \\
\hline & Student & 123 & 39.9 \\
\hline & Housewife & 12 & 3.9 \\
\hline & Others & 1 & 0.3 \\
\hline & $<1$ Hours & 6 & 1.9 \\
\hline \multirow{3}{*}{$\begin{array}{l}\text { Internet usage per } \\
\text { day }\end{array}$} & 1-3 Hours & 69 & 22.4 \\
\hline & 4-6 Hours & 131 & 42.5 \\
\hline & $>7$ Hours & 102 & 33.1 \\
\hline
\end{tabular}

Source: authors own calculations

\section{Results}

To extract categories of perceived benefits, principal component analysis was conducted on the grounds of Eign-value and KMO (Kaiser-Meyer-Olkin). KMO test showed sample adequacy of 0.906 that is interpreted as excellent and suitable for rotated factor analysis (Hutcheson \& Sofroniou, 1999). The rotated factor matrix categorized perceived benefits into four groups as presented in Table 2. The perceived benefits are sorted according to variance explained, so hedonic benefits showed 23.38 of variance by loading four items. Second category comprises learning benefits which explained a variance of 21.05 by loading three items. Thirdly, items related to self-esteem presented a variance of 18.56 by loading two items. The fourth category of benefits includes social factors which explained variance of 16.40 by loading three items. Based on these results, we analyzed the relationship perceived benefits with OBC participation, value creation and brand loyalty. 
Table 2: Principal component analysis of perceived benefits in Online brand Community (OBC)

\begin{tabular}{lll}
\hline Motive (Eigen-value) & Loading & Variance explained \\
\hline Hedonic benefits & & 23.38 \\
Feel pleased and relaxed & 0.846 & \\
Gain joy and happiness & 0.818 & \\
Feel inspired & 0.711 & \\
Feel sense of satisfaction & 0.563 & \multirow{2}{*}{21.05} \\
Learning benefits & & \\
Understanding of components and technical development & 0.858 & \\
Solve problem associated to brand & 0.798 & \\
Increase knowledge & 0.785 & \multirow{2}{*}{18.56} \\
Self-esteem benefits & & \\
Increase credibility and authority & 0.827 & \\
Enhance status and reputation & 0.799 & \multirow{2}{*}{16.40} \\
Social benefits & & \\
Strengthen connection with other members & 0.757 & \\
Expand social network & 0.741 & \\
People share common interest & 0.514 & \\
\hline
\end{tabular}

Source: authors own calculations

Table 3: Correlation, mean, standard deviation of variables

\begin{tabular}{|c|c|c|c|c|c|c|c|c|c|c|c|c|c|}
\hline & & Mean & $\begin{array}{l}\text { Std. } \\
\text { Dev }\end{array}$ & 1 & 2 & 3 & 4 & 5 & 6 & 7 & 8 & 9 & 10 \\
\hline 1 & $\begin{array}{l}\text { Duration o } \\
\text { membership }\end{array}$ & of 2.44 & 1.55 & 1.00 & & & & & & & & & \\
\hline 2 & $\begin{array}{l}\text { Degree } \\
\text { visiting }\end{array}$ & of 3.03 & 1.69 & $-.31^{* *}$ & 1.00 & & & & & & & & \\
\hline 3 & $\begin{array}{l}\text { Level o } \\
\text { posting/like }\end{array}$ & of 4.61 & 1.21 & $-.27^{* *}$ & $.44^{* *}$ & 1.00 & & & & & & & \\
\hline 4 & $\begin{array}{l}\text { Learning } \\
\text { benefits }\end{array}$ & 4.39 & 1.24 & $.15^{* *}$ & $-.24^{* *}$ & .10 & 1.00 & & & & & & \\
\hline 5 & $\begin{array}{l}\text { Social } \\
\text { benefits }\end{array}$ & 3.94 & 1.32 & $.132^{*}$ & $-.26^{* *}$ & $.27^{* *}$ & $.59^{* *}$ & 1.00 & & & & & \\
\hline 6 & $\begin{array}{l}\text { Self-esteem } \\
\text { benefits }\end{array}$ & 3.41 & 1.38 & -.31 & $-.14^{* *}$ & $.16^{* *}$ & $.32^{* *}$ & $.70^{* *}$ & 1.00 & & & & \\
\hline 7 & $\begin{array}{l}\text { Hedonic } \\
\text { benefits }\end{array}$ & 4.04 & 1.30 & .076 & $-.30^{* *}$ & $.26^{* *}$ & $.53^{* *}$ & $.72^{* *}$ & $.68^{* *}$ & 1.00 & & & \\
\hline 8 & $\begin{array}{l}\mathrm{OBC} \\
\text { participation }\end{array}$ & n 3.79 & 1.37 & .106 & $-.30^{* *}$ & $.25^{* *}$ & $.51^{* *}$ & $.75^{* *}$ & $.66^{* *}$ & $.72^{* *}$ & 1.00 & & \\
\hline 9 & $\begin{array}{l}\text { Value } \\
\text { creation }\end{array}$ & 4.17 & 1.20 & $.15^{* *}$ & $-.30^{* *}$ & $.24^{* *}$ & $.67^{* *}$ & $.73^{* *}$ & $.57^{* *}$ & $.77^{* *}$ & $.86^{* *}$ & 1.00 & \\
\hline & Brand loyalty & ty 4.56 & 1.30 & $.19^{* *}$ & $-.19 * *$ & $.12^{* *}$ & $.47^{* *}$ & $.37^{* *}$ & $.20^{* *}$ & $.38^{* *}$ & $.42^{* *}$ & $.56^{* *}$ & 1.00 \\
\hline
\end{tabular}

**. Correlation is significant at the 0.001 level (2-tailed).

*. Correlation is significant at the 0.05 level (2-tailed).

Source: authors own calculations

Bivariate analyses are conducted for investigating mean, standard deviation and inter-constructs correlation, the outcome is presented in Table 3. OBC traits showed that membership duration is negatively significant will level of visiting and posting in an OBC. However, level of posting is positively related with level of visiting the brand page at $\mathrm{p}<.001$. The level of posting presented a mean of 4.61 which exhibit that members post or comment on a brand community "once a month" while level of visiting presented a mean of 3.03 which demonstrate that members visit a brand page "every two weeks". The perceived benefits showed a strong 
correlation with $\mathrm{OBC}$ participation, value creation and brand loyalty at $\mathrm{p}<0.001$. Therefore, we summarized that level of visiting and posting impact online brand community participation while perceived benefits are positive determinants of OBC participation, value creation and brand loyalty.

The relationship of perceived benefits and $\mathrm{OBC}$ participation was examined through linear regression which demonstrated $\mathrm{R} 2=65.1 \%$ and Adj.R2 $=64.7 \%$ at $\mathrm{p}<0.001$ as shown in Table 4 . Social benefits presented $(\beta$ $=.357, \mathrm{p}<.001)$ followed by hedonic benefits with $(\beta=.035, \mathrm{p}<.001)$ and self-esteem with $(\beta=.184, \mathrm{p}<.001)$ which means that $1 \%$ increase in social benefits will increase OBC participation by $35.7 \%$ followed by hedonic benefits will increase OBC participation by $39.6 \%$. However, learning benefits showed $(\beta=.087$, $\mathrm{p}<.05)$ which means that learning benefits are significant at $95 \%$ confidence interval. Based on these results, we accept H1a, H1b, H1c \& H1d at p<0.05. Thus, we summarize that these four categories of perceived benefits predicted $65 \%$ of $\mathrm{OBC}$ participation. So, marketers can target these perceived benefits for promoting members $\mathrm{OBC}$ participation.

Table 4: Regression analysis of online brand community participation

\begin{tabular}{llll}
\hline Dependent variable & \multicolumn{3}{l}{ Online brand community } \\
Predictors & $\boldsymbol{\beta}$ & Sig. & $\boldsymbol{t}$ \\
\hline$\alpha$ & .035 & .851 & .188 \\
Hedonic benefits & $.296^{* *}$ & .000 & 5.39 \\
Learning benefits & $.087^{*}$ & .051 & 1.96 \\
Social benefits & $.357^{* *}$ & .000 & 6.04 \\
Self-esteem benefits & $.184^{* *}$ & .001 & 3.48 \\
$\mathrm{R}$ & .807 & & \\
$\mathrm{R}^{2}$ & $.651^{* *}$ & & \\
Adjusted $\mathrm{R}^{2}$ & .647 & & \\
\hline${ }^{* *} p<0.001,{ }^{*} p<0.05$ & & \\
Source: authors own calculations &
\end{tabular}

The investigation of $\mathrm{OBC}$ participation and value creation is conducted through multi-regression analysis by considering consumer knowledge as moderator. The interaction term was generated to examine this relationship which highlighted that OBC participation $(\beta=.808 \mathrm{p}<.001)$ and consumer knowledge $(\beta=.168$, $\mathrm{p}<.001$ ) are strong predictor of value creation in an $\mathrm{OBC}$ by presenting a $\mathrm{R} 2=77.6 \%$ and adj- $\mathrm{R} 2=77.5 \%$ as given in (model-1) while the effect of moderator term shown negative significant with value creation $(\beta=-$ $0.103, \mathrm{p}<.001$ ) by presenting $\mathrm{R} 2=78.7 \%$ and adj-R2 $=78.5 \%$ as given in (model-2). This result revealed that when consumer knowledge moderate online brand community participation, it decrease value creation attributes as shown in Table 5. These attributes are essential to relationship management but majority of member seldom visit brand pages not to participate but to expand their social network and pass their leisure time. Therefore, we accept $\mathrm{H}_{2}$ and $\mathrm{H}_{3}$ because participation and consumer knowledge act as antecedents for value creation and when this relationship consider consumer knowledge as moderator, it shown negative impact on value creation for online brand communities.

Table 5: Regression analysis of value creation with interaction \& without interaction

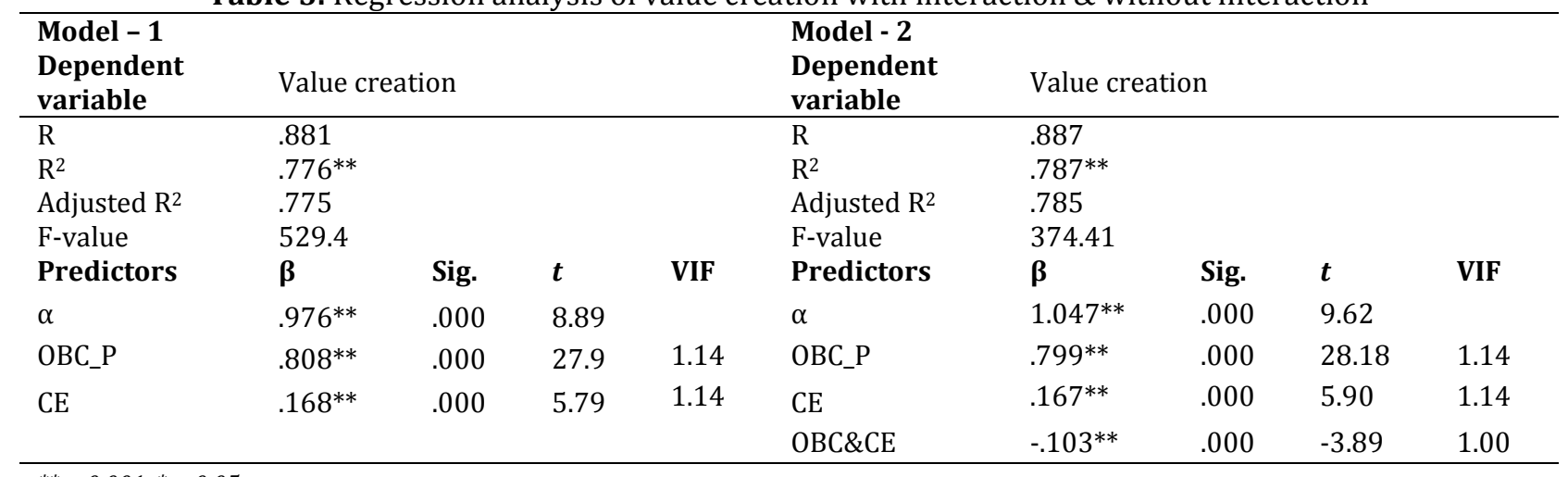

${ }^{* *} p<0.001,{ }^{*} p<0.05$ 
$O B C_{-} P=$ online brand community participation

$C E=$ consumer knowledge about brand, before joining $O B C$

$O B C \& C E=$ interaction term $O B C_{-} P^{*} C E$

Source: authors own calculations

(Table 6) present the relationship of OBC participation and value creation with Overall brand. According to the results, we accepted $\mathrm{H}_{4 \mathrm{a}}$ and $\mathrm{H}_{4 \mathrm{~b}}$ with $\mathrm{R} 2=33.3 \%$ and Adj.R2 $=32.8 \%$ at $\mathrm{p}<0.001$. Online brand community participation presented $(\beta=.250, p<.001)$ and value creation practices presented $(\beta=.530, p<.001)$. So, this relationship describe that $1 \%$ increase in value creation practices will increase brand loyalty by $53.0 \%$ and $1 \%$ increase in OBC participation will lead to $25.0 \%$ increase in overall brand loyalty. The brand managers must focus on value creation practices to boost the corporate strategy through overall brand loyalty.

Table 6: Regression analysis of Brand loyalty in online brand communities

\begin{tabular}{llcl}
\hline Dependent variable & \multicolumn{3}{c}{ Overall Brand loyalty } \\
Predictors & $\boldsymbol{\beta}$ & Sig. & $\boldsymbol{t}$ \\
\hline$\alpha$ & $1.944^{* *}$ & .000 & 8.765 \\
Online brand community participation & $.250^{* *}$ & .008 & 2.664 \\
Value Creation & $.530^{* *}$ & .000 & 8.307 \\
$\mathrm{R}$ & .577 & & \\
$\mathrm{R}^{2}$ & $.333^{* *}$ & & \\
Adjusted $\mathrm{R}^{2}$ & .328 & & \\
\hline
\end{tabular}

${ }^{* *} p<0.001,{ }^{*} p<0.05$

Source: authors own calculations

Discussion: Value creation for brand communities is very decisive concern for managers and marketers, particularly while attracting new community members, existing consumer and increasing brand relationships. The study presents an investigation for capturing value-creation practices based on perceived benefits. Value creation practices influences overall brand loyalty which demonstrated that when consumer participate in an $\mathrm{OBC}$ he/she create value proposition for a brand that resulted in retaining and maintaining relationship with product/brand. Thus, it provides opportunities to brand managers to ponder the attributes that provide competitive advantage in market place. This study contributes considerable scientific evidence about operative factors of consumer behavior that are based on unique attributes of value creation for a customer. While, prior studies demonstrate links between social networking sites and brand communities based on the interaction and accessibility such as (Kietzmann et al., 2011). Moreover, this study elaborates the drivers of online brand communities with explicit focus on value creation. The exclusive attributes that drive consumer to engage in a brand activities are brought forward for marketing managers for reaching target consumers through such attributes of brand community. Nowadays, brands are investing their valuable resources to acquire market share and consumer trust which cause competition and increase marketing expenses (Casalo et al., 2008). Brand managers need to involve themselves in eternal relationship with consumers that could be beneficial for developing value creation which provide consumer retention and participation (Andersen, 2005).

\section{Conclusion}

The value creation practices generate collaboration between consumers and brand by involving them in communal activities like: social-networking or impression management. In recent times, organizational objectives have extensively transformed form tangible resources to intangible resources which hold organizational intellectual value. The results indicated guidelines for brand managers about building a strong brand based on consumer insights. Therefore, to get competitive advantage organization need to monitor their relationship with consumer through OBCs because it provides value and intangible resources for businesses. This study has several contributions for academic scholars: Firstly, this study revealed promising value-added attributes from consumer perspective that help in investigating crowd-sourcing. This assessment compares the domain of virtual environment which other communication channels used by organization for creating customer-brand relationship. Secondly, the outcome of OBC benefits provides vital successful attributes while creating customer value for a brand/product in terms of virtual network 
expansion. Thirdly, it delivers the sources of customer value in an $\mathrm{OBC}$ that could act as principal adoption attributes for consumer engagement in brand communities. The managerial implications could provide opportunities for newly established brands or less-renowned brands to create value for their brand in the mind of consumer through social media. A detailed investigation of value creation practices have provided new outcome from consumer perspective, thus future research should focus on this domain. Brand loyalty in online brand communities varies as compared to traditional brand loyalty, so new direction should be explored to define brand loyalty in online brand communities. The study faced limitation like regional constraint because sample is collected from China, therefore dataset based on international respondents might be interesting for further studies.

Acknowledgment: This research is sponsored by the "National Natural Science Foundation of China under Grant 71272125" and "Fundamental Scientific and Research Program of Chinese Central Universities under Grant 2014QN207"

\section{Reference}

Adjei, M., Noble, S. \& Noble, C. (2010). The influence of C2C communications in online brand communities on customer purchase behavior. Journal of the Academy of Marketing Science, 38(5), 634-653.

Ambler, T. (1992). Need-to-Know-Marketing, Century Business, London.

Andersen, P. H. (2005). Relationship marketing and brand involvement of professionals through webenhanced brand communities: the case of Coloplast. Industrial Marketing Management, 34(1), 3951. http://dx.doi.org/10.1016/j.indmarman.2004.07.002.

Casaló, L. V., Flavián, C. \& Guinalíu, M. (2008). Promoting consumer's participation in virtual brand communities: A new paradigm in branding strategy. Journal of Marketing Communications, 14(1), 19-36. http://dx.doi.org/10.1080/13527260701535236.

Coleman, J. S. (1988). Social capital in the creation of human capital. American Journal of Sociology, 94, 95-120.

Cova, B. \& Pace, S. (2006). Brand community of convenience products: New forms of customer empowerment: The case 'My Nutella the Community. European Journal of Marketing, 40, 1087-1105.

Dholakia, U. M., Bagozzi, R. P. \& Pearo, L. K. (2004). A social influence model of consumer participation in network- and small-group-based virtual communities. International Journal of Research in Marketing, 21, 241-263.

Grayson, K. \& Martinec, R. (2004). Consumer perceptions of iconicity and indexicality and their influence on assessments of authentic market offerings. Journal of Consumer Research, 31(2), 296-312.

Habibi, M. R., Laroche, M. \& Richard, M. O. (2014). Brand communities based in social media: How unique are they? Evidence from two exemplary brand communities. International Journal of Information Management, 34(2), 123-132.

Hanna, R., Rohm, A. \& Crittenden, V. L. (2011). We're all connected: The power of the social media ecosystem. Business Horizons, 54(3), 265-273.

Hutcheson, G. D. \& Sofroniou, N. (1999). The multivariate social scientist: Introductory statistics using generalized linear models. Sage.

Kapferer, J. N. \& Bastien, V. (2009). The specificity of luxury management: Turning marketing upside down. Journal of Brand Management, 16(5), 311-322.

Kaplan, R. S. \& Norton, D. P. (2000). Having trouble with your strategy? Then map it. Harvard Business School Publishing Corporation.

Katz, E., Gurevith, M. \& Haas, H. (1973). On the use of the mass media for important things. American Sociological Review, 38, 164-181.

Keller, K. L. (1993). Conceptualizing, measuring, and managing customer-based brand equity. The Journal of Marketing, 1-22. http://dx.doi.org/10.2307/1252054.

Kietzmann, J. H., Hermkens, K., McCarthy, I. P. \& Silvestre, B. S. (2011). Social media? Get serious! Understanding the functional building blocks of social media. Business Horizons, 54(3), 241-251.

Kozinets, R. V. \& Kedzior, R. (2009). I, Avatar: Auto-netnographic Research in Virtual Worlds. Virtual Social Identity and Consumer Behavior, 2, 3-19.

Kozinets, R., de Valck, K., Wojinicki, A. C. \& Wilner, S. (2010). Networked narratives: Understanding word-ofmouth marketing in online communities. Journal of Marketing, 74, 71-89. 
http://dx.doi.org/10.1509/jmkg.74.2.71.

McAlexander, J. H., John, S. W. \& Koening, F. H. (2002). Building brand community. Journal of Marketing, 66, 38-54. http://dx.doi.org/10.1509/jmkg.66.1.38.18451.

McWilliam, G. (2000). Building stronger brands through online communities. Sloan Management Review, 41(3), 43-54.

Muniz, Jr. A. M. \& O'Guinn, T. C. (2001). Brand community. Journal of consumer research, 27(4), 412-432. http://dx.doi.org/10.1086/319618.

Muniz, A. \& Schau, H. J. (2005). Religiosity in the abandoned Apple Newton brand community. Journal of Consumer Research, 31, 737-747. http://dx.doi.org/10.1086/426607.

Nambisan, S. \& Baron, R. A. (2009). Virtual customer environments: Testing a model of voluntary participation in value co-creation activities. Journal of Product Innovation Management, 26(4), 388406. http://dx.doi.org/10.1111/j.1540-5885.2009.00667.x

Ouwersloot, H. \& Odekerken-Schröder, G. (2008). Who's who in brand communities-and why?. European Journal of Marketing, 42(5/6), 571-585. http://dx.doi.org/10.1108/03090560810862516

Powers, T., Advincula, D., Austin, M. S., Graiko, S. \& Snyder, J. (2012). Digital and Social Media in the Purchase Decision Process A Special Report from the Advertising Research Foundation. Journal of advertising research, 52(4), 479-489.

Schau, H. J., Muñiz, A. M. Jr. \& Arnould, E. J. (2009). How brand community practices create value. Journal of Marketing, 73(5), 30-51. http://dx.doi.org/10.1509/jmkg.73.5.30

Schouten, J. W., McAlexander, J. H. \& Koenig, H. F. (2007). Transcendent customer experience and brand community. Journal of the Academy of Marketing Science, 35(3), 357-368.

Sicilia, M. \& Palazon, M. (2008). Brand communities on the internet: A case study of Coca-Cola's Spanish virtual community. Corporate Communications: An Inter-national Journal, 13(3), 255-270. http://dx.doi.org/10.1108/13563280810893643.

Tajfel, H. \& Turner, J. C. (1985). The social identity theory of intergroup behavior. InS. Worchel, \& W. G. Austin (Eds.), Psychology of intergroup relations (pp. 7-24).Chicago: Nelson Hall.

Thompson, S. A. \& Sinha, R. K. (2008). Brand communities and new product adoption: the influence and limits of oppositional loyalty. Journal of Marketing, 72(6), 65-80.

Wang, Y. C. \& Fesenmaier, D. R. (2004). Modeling participation in an online travel community. Journal of Travel Research, 42(3), 261-270. http://dx.doi.org/10.1177/0047287503258824.

Wirtz, J., Den Ambtman, A., Bloemer, J., Horváth, C., Ramaseshan, B., Van De Klundert, J. \& Kandampully, J. (2013). Managing brands and customer engagement in online brand communities. Journal of Service Management, 24(3), 223-244. http://dx.doi.org/10.1108/09564231311326978.

Woisetschläger, D. M., Hartleb, V. \& Blut, M. (2008). How to Make Brand Communities Work: Antecedents and Consequences of Consumer Participation. Journal of Relationship Marketing, 7(3), 237-256.

Yen, H. R., Hsu, S. H. Y. \& Huang, C. Y. (2011). Good soldiers on the web: Under-standing the drivers of participation in online communities of consumption. International Journal of Electronic Commerce, 15(4), 89-120. http://dx.doi.org/10.2753/JEC1086-4415150403.

Yoo, W. S., Suh, K. S. \& Lee, M. B. (2002). Exploring the factors enhancing member participation in virtual communities. Journal of Global Information Management (JGIM), 10(3), 55-71. 